\title{
Ph.D training by specialty "Law» in Ukraine (on the example of Zaporizhzhia National University)
}

\section{Formación de doctorado por especialidad «Derecho» en Ucrania (en el ejemplo de la Universidad Nacional Zaporizhzhia)}

\author{
Mikhail Larkin \\ malark777@ukr.net \\ https://orcid.org/0000-0002-4676-460X \\ Ph. D., Associate Professor of Department of Criminal Law and Justice of Zaporizhzhia \\ National University. \\ Svitlana Poliakova \\ polyana729@ukr.net \\ https://orcid.org/0000-0002-5138-605X \\ Ph. D., Vice-Rector for social and humanitarian and proforientation work \\ (Dniprovsky Humanitarian University) \\ Oleksandr Shamara \\ alexandr79shamara@gmail.com \\ https://orcid.org/ 0000-0002-0571-0437 \\ Ph.D., senior scientific officer, Professor of the Department of Law \\ (Dniprovsky Humanitarian University) \\ Natalia Ivanova \\ ins210218@gmail.com \\ https://orcid.org/0000-0001-8693-3255 \\ Candidate of Political Science, Associate Professor, Associate Professor of the \\ Department of Law, Berdyansk State Pedagogical University. \\ Iryna Petiahina \\ petyagina@gmail.com \\ https://orcid.org/0000-0002-5478-7393 \\ Senior Lecturer at the Department of Law, Berdyansk State Pedagogical University.
}

Recibido: $23 / 05 / 21$

Aceptado: 30/06/21

\begin{abstract}
The process of training candidates for the degree of Doctor of Philosophy $(\mathrm{PhD})$ in Ukraine, which is aimed at the formation of theoretical and applied competencies, consists of two blocks: theoretical and practical. The authors have considered the main stages of training of applicants. The purpose of this work is to analyze the peculiarities of the training of doctors of philosophy in the specialty "Law" in Ukraine. The object of
\end{abstract}


research is the peculiarities of the training of doctors of philosophy in the specialty "Law". The subject of the research is the peculiarities of training doctors of philosophy in the specialty "Law" on the example of Zaporizhzhia National University. The following methods were used during the study: analysis and synthesis, extrapolation, modeling, comparison, observation, generalization, the ascent from the abstract to the concrete, induction, and deduction, morphological analysis method, information method, commission method. During the study, the features of theoretical and practical aspects of training doctors of philosophy in the specialty "Law" were analyzed, trends in training doctors of philosophy were identified, relevant areas for further study, and improvement of the process of obtaining the degree of doctor of philosophy were identified.

Key Words: Ph.D., derecho, formación teórica, formación práctica.

\section{Resumen}

El proceso de formación de candidatos para el grado de Doctor en Filosofía (PhD) en Ucrania, que tiene como objetivo la formación de competencias teóricas y aplicadas, consta de dos bloques: teórico y práctico. Los autores han considerado las principales etapas de formación de los solicitantes. El propósito de este trabajo es analizar las peculiaridades de la formación de los doctores en filosofía en la especialidad "Derecho" en Ucrania. El objeto de la investigación son las peculiaridades de la formación de los doctores en filosofía en la especialidad "Derecho". El tema de la investigación son las peculiaridades de la formación de doctores en filosofía en la especialidad "Derecho" en el ejemplo de la Universidad Nacional de Zaporizhzhia. Durante el estudio se utilizaron los siguientes métodos: análisis y síntesis, extrapolación, modelado, comparación, observación, generalización, ascenso de lo abstracto a lo concreto, inducción y deducción, método de análisis morfológico, método de información, método de comisión. Durante el estudio se analizaron las características de los aspectos teóricos y prácticos de la formación de los doctores en filosofía en la especialidad "Derecho", se identificaron las tendencias en la formación de los doctores en filosofía, las áreas relevantes para profundizar en el estudio y la mejora del proceso de obtención del grado de se identificaron doctores en filosofía.

Palabras clave: responsabilidad penal, provocación de cohecho, lucro ilícito, provocador, persona provocada.

\section{Introduction}

Systemic changes in higher education in Ukraine, which are caused by the processes of the global transformation of the world perception, were a natural result of the harmonization of the current legislation. Thus, the new law "On Higher Education" (Law 1556-VII, 2014) adopted in 2014 has conceptually changed the approaches in the educational sphere. This law (part 1 of Article 5) considers 4 levels of higher education: initial level (short cycle) of higher education; first (bachelor's) level; se cond (master's) 
level; third (educational-scientific / educational-creative) level. Obtaining higher education at each level of higher education provides for the successful implementation of an educational program by a person and is the basis for awarding an appropriate higher education degree:

1) junior bachelor;

2) bachelor's degree;

3) master's degree, and;

4) Doctor of Philosophy / Doctor of Art (Part 2 of Article 5).

These levels are also regulated by the National Qualifications Framework, which is a systematic and structured description of qualification levels of education, intended for use by executive authorities, institutions and organizations implementing state policy in education, employment and social relations, educational institutions, employers, other legal entities and individuals for development, identification, correlation, recognition, planning, and development of qualifications (Ministry of Education and Science of Ukraine, 2021; Rashkevych, 2020). The principal legislative act regulating the National Qualifications System was the Law of Ukraine "On Education" (Law 2145-VIII, 2017) adopted on September 5, 2017. Thus, following Part 2 of Art. 35 of the Law 2145-VIII states that the National Qualifications Framework is intended for use by public authorities and local governments, institutions and organizations, educational institutions, employers, other legal entities, and individuals for the purpose of development, identification, correlation, recognition, planning, and development qualifications.

The entire European and North American university education system recognizes the Doctor of Philosophy (Ph.D.) degree as the highest level in the academic environment. A feature of the American system is that a higher educational institution decides for itself whom to accept for study, and, therefore, the value of previous diplomas is not so great. Personal reputation and the recommendation of a specific teacher who believes that the applicant can complete the scientific work are mandatory. The research project is also of great importance, the applicant must submit it to the university to be admitted. Since training is paid, this removes the problem of low motivation and formalism. At the same time, there is a developed system of grant support for doctoral programs. After receiving a doctorate, a specialist, as a rule, does not stay to teach at the same university where he studied but looks for a job elsewhere (Panych, 2018).

There is also a doctorate in philosophy in Europe. In particular, in Poland and Germany, admission to the doctoral program is based on a master's degree (Panych, 2017), given that these countries are participants in the Bologna Process, which provides for a twolevel cycle (first and second cycle). It is the second cycle that includes, among others, obtaining a doctorate (Stepko, Bolyubash, Shinkaruk, Grubinko \& Babyn, 2003).

Common in most European countries are the procedures for training and certification of degree seekers are mostly carried out based on professional self-regulation by 
universities themselves with relatively little regulation by ministries or agencies (Panych, 2018).

The degree of Doctor of Philosophy (Ph.D.) abroad does not correlate with the degree of Doctor of Science in Ukraine, because obtaining the specified degree (with rare exceptions) is preceded by the defense of a dissertation of a candidate of sciences, which, in fact, is equivalent to a doctor of philosophy (Ph.D.). However, the system of training doctors of philosophy in Ukraine is qualitatively different from the training of candidates of science.

High-quality training of applicants for higher education for the degree of Doctor of Philosophy is a guarantee of highly qualified scientific and scientific-pedagogical personnel (Onishchuk, 2020).

We would like to analyze the features of the theoretical and practical components of postgraduate studies in the specialty 081 Law based on an analysis of the educational and scientific program of Zaporizhzhia National University at 2021 and individual local regulations.

\section{Theoretical framework}

During the writing of the article, normative legal acts were used, which regulate public relations in the field of obtaining the scientific degree of Doctor of Philosophy. Another essential element of the study was the study and analysis of legislation in the field of higher education in Ukraine.

The fundamental provisions for studying the peculiarities of obtaining the degree of Doctor of Philosophy in the specialty "Law" are contained in the following regulations: Laws of Ukraine "On Higher Education" (Law 1556-VII, 2014), "On Education" (Law 2145-VIII, 2017), the Cabinet of Ministers Resolution "On Approval of the Procedure for Training Higher Education Degrees of Doctor of Philosophy and Doctor of Science in Higher Educational Institutions" (Resolution 261, 2016), On the practice of third-level applicants for the degree of Doctor of Philosophy at Zaporizhzhia National University (Regulations 184, 2019), on the procedure for carrying out innovative educational activities (Regulations 522/2000). Thus, the Law of Ukraine "On Education" (Law 2145-VIII, 2017) defines the legal status of the National Qualifications Framework, the Law of Ukraine "On Higher Education" (Law 1556-VII, 2014) establishes the legal basis for higher education, in particular, based on its rules drafted internal regulations of higher education institutions governing the degree of Doctor of Philosophy. For example, the right to choose academic disciplines is provided (paragraph 15, part 1 of Article 62 of the Law).

One of the key sources of information about the state of obtaining the degree of Doctor of Philosophy in "Law" were the internal documents of Zaporizhzhia National University, which regulate: 
- the order of theoretical training of applicants for higher education, in particular, the Regulations on the realization of the right of applicants for the third level of higher education degree of Doctor of Philosophy to free choice of disciplines at Zaporizhzhia National University defines the order of choice of disciplines;

- the order of practical training of applicants for higher education. This component of obtaining the degree of Doctor of Philosophy is regulated by the Regulations on the practice of third-level graduates of the degree of Doctor of Philosophy at Zaporizhzhia National University. This document defines the procedure for pedagogical, and research practice by graduates of the degree of Doctor of Philosophy sets requirements for its program, content, evaluation of practice results.

The principal part of scientific works is devoted to the general problems of reforming higher education in Ukraine. In particular, relevant for analysis in the context of this study are works devoted to the commentary of the new edition of the National Qualifications Framework of Rashkevych (2020), problematic aspects of training doctors of doctors, scientists, international practice of organizing the process of obtaining the degree of Doctor of Philosophy by Stepko, Bolyubash, Shinkaruk, Grubinko, amd Babyn (2003).

Given the small number of scientific papers on the training of doctors of philosophy, further study is needed to expand the theoretical aspects of the preparation of doctors of philosophy; organizational system of motivation of scientific activity; international cooperation in scientific and educational programs, etc.

\section{Methodology}

While working on the article, the normative base of Zaporizhzhia National University, scientific and journalistic literature devoted to the pedagogy of education were analyzed. In addition, a set of different scientific methods was used. Among them: observation (in the study of the educational and scientific program, local regulations, which became the basis for the formulation of several provisions of the article), analysis (in the study of legal documents and literature sources on the training of doctors of philosophy in "Law". Thus, the main sources for a comprehensive analysis were the provisions of the Law of Ukraine "On Higher Education" (Law 1556-VII, 2014), "On Education" (Law 2145-VIII, 2017), the Cabinet of Ministers Resolution "On Approval of the Procedure for Training Higher Education Degrees of Doctor of Philosophy and Doctor of Science in Higher Educational Institutions" (Resolution 261, 2016), etc.; scientific works of Panych (2017, 2018), Stepko, Bolyubash, Shinkaruk, Grubinko, amd Babyn (2003), Rashkevych (2020), where important for research provisions which need to be qualitatively and reasonably stated are contained), synthesis (when summarizing some recommendations for the training of doctors of philosophy in the specialty "Law"), extrapolation (in the study of scientific sources on the training of doctors of philosophy in the specialty "Law", namely in the works of Panych (2018), the degree of Doctor of Philosophy is considered a universal concept in characterizing the third level of higher education, which allowed to transfer them to a specialty "Law"), generalization (to formulate conclusions based on a structured and consistent presentation of the material), the method of comparison was used when 
comparing systems for obtaining the degree of Doctor of Philosophy in countries such as the United States, Germany, and Poland. In addition, the experimental method for formation as a kind of experimental method is aimed at transforming, improving the quality of the studied object by identifying relevant issues for the further theoretical basis of the third level of higher education.

The method of ascent from the abstract to the concrete helped to find among the small number of doctrines in the field of the degree of Doctor of Philosophy to find among the general provisions specific theoretical and practical aspects of obtaining the degree of Doctor of Philosophy.

Methods of induction and deduction have been useful in formulating the results of the study because in formulating conclusions it is necessary to find judgments that go from general statements to private and vice versa.

When using the modeling method, a model of obtaining the degree of Doctor of Philosophy was revealed on the example of Zaporizhzhia National University as a way to find advantages and improve it by other educational institutions.

The use of the commission method (a variant of the method of expert evaluations) allowed to choose the most objective and substantiated on the basis of a set of different opinions of experts, which in this study was revealed in the disclosure of research and innovation as one of the elements of training at the third level.

The information method made it possible to quickly and efficiently obtain information from various sources on selected issues, such as scientific literature, periodicals, the Internet, etc.

The method of morphological analysis helped to ensure the division of the selected issues into constituent parts (a theoretical and practical aspect of training third-level applicants for higher education).

\section{Results and discussion}

\subsection{Theoretical training of doctors of philosophy (PhD) in the specialty "Law"}

Theory and practice are not the same things... However, one must seek a synthesis of theory and practice. It is a synthesis, not just a combination of them. No wonder they say that there is nothing more practical than a good theory (Kornev, 2018), taking into account the social conditionality of law should be expressed by the adequacy of law to social relations, which are regulated by (Trebin, 2010). This is what is taken into account when teaching academic disciplines in graduate school. 
The study of academic disciplines within the framework of a four-year course for the preparation of doctors of philosophy in the specialty "Law" consists of two blocks of disciplines:

1) compulsory disciplines (general training cycle and vocational training cycle), and;

2) the discipline of choice.

The choice of disciplines at Zaporizhzhia National University is provided by the Regulations on the implementation of the right of third-level graduates of the degree of Doctor of Philosophy to free choice of disciplines at Zaporizhzhia National University from May 30, 2018, No 190 (Regulations No. 190, 2018).

According to this document, the initial disciplines professional training and account for at least $25 \%$ of the total number of ECTS credits of the educational component of the educational and scientific program. Also, disciplines should be selected under the subject of the dissertation research of the applicant. The choice of disciplines is made using the system of electronic learning (Moodle system). It should be noted that the Regulation meets the provisions of the Law of Ukraine "On Higher Education" of July 07, 2014, No. 1556-VII, namely paragraph 15 of Part 1 of Art. 62 (Law 1556-VII, 2014)

Separately, I would like to dwell on the possibility, within the framework of studying the disciplines of general training, the participation of each applicant in grant activities. A survey of applicants showed that each applicant has the opportunity to take part in grant projects. Teachers of individual disciplines pay great attention to drawing up applications for grants and have developed appropriate methodological recommendations.

The Law of Ukraine "On Higher Education" (Law 1556-VII, 2014) provides for the right of scientific institutions to train doctors of philosophy according to their own educational and scientific program following the obtained license for relevant educational activities or educational and scientific program, some elements of which are provided by other scientific institutions and/or institutions of higher education (paragraph 4, part 6, Article 5 of the Law).

According to the Procedure for training higher education candidates for the degree of Doctor of Philosophy and Doctor of Science in higher educational institutions (scientific institutions), approved by the Cabinet of Ministers of Ukraine dated March 23, 2016, No. 261 training for higher education for the degree of Doctor of Philosophy (Resolution 261, 2016):

- in graduate school (postgraduate) of a higher education institution (scientific institution) for full-time (full-time, evening) or correspondence form of education, and;

- outside postgraduate studies (for persons who professionally conduct scientific, scientific-technical, or scientific-pedagogical activities at the central place of work in the relevant institution of higher education (scientific institution). 
Given that the training of doctors of philosophy is carried out by higher education institutions, including for their own needs, determining the role and place of research and innovation activities of universities is of particular importance in the context of shaping the content of educational and scientific programs of future doctors of philosophy.

According to the Regulations on the procedure for carrying out innovative educational activities, approved by the Order of the Ministry of Education and Science of Ukraine dated November 07, 2000, No. 522, "innovative activities in the education system are defined as activities aimed at developing and using research results in education" (Regulations 522, 2000).

Research activity is a specific human activity, regulated by the consciousness and activity of the individual, aimed at meeting cognitive, intellectual needs, the product of which is new knowledge obtained per the goal, objective laws, and existing circumstances that determine the reality and achievability of the purpose. Determining specific ways and means of action, through problem statement, isolation of the object of study, experiment, description, and explanation of the facts obtained in the experiment, creating a hypothesis (theory), forecasting and testing the knowledge, determine the specifics and essence of this activity (Zimnyaya, \& Shashenkova, 2001).

Research and innovation can be defined as a complex innovation aimed at obtaining new knowledge, their formalization in the form of a specific product, and its practical use to obtain a particular effect for the benefit of society.

In general, research and innovation activities can be divided into stages:

1. Development of the idea of conducting research;

2. Development of new knowledge, and;

3. Creating innovations.

A promising area of further research is to determine the content, types, and forms of research and innovation training at the third level of higher education.

\subsection{Practical training of doctors of philosophy $(P h D)$ in the specialty "Law"}

The practical component of the preparation of applicants is the most significant element of the learning process and writing a dissertation. Each dissertation is an attempt to solve a practical topical problem (accordingly, the choice of a research topic is considered). Schiller wrote: "Every person is a citizen of his time, just like a citizen of his state; and if it is considered unacceptable and even unlawful to be distinguished by mores and customs from the circle in which you live, then should you consider it equally obligatory for yourself to be guided by the taste and needs of your age in your choice of activity?" (Schiller, 2018). 
The use of advanced ideas of legal science is taking into account the well-established legal theories. Interesting in this context is the thought of Chesterfield: "We had to fight for an advanced worldview while preserving all the old prejudices and traditions that have long outlived themselves" (Chesterfield, 2010).

An integral part of the practical training of applicants for the specialty "Law" at Zaporizhzhia National University is the passage of teaching and research practice.

Passage of teaching practice is the most significant stage in the professional growth of an applicant. The bases for passing pedagogical practice are the departments of the Zaporizhzhia National University, to which the applicants are assigned.

The direct supervision of the pedagogical practice of each applicant is carried out by his supervisor.

The program of pedagogical practice provides the following types of work (Regulations 184, 2019):

- acquaintance with the normative documents regulating the rights and duties of scientific and pedagogical workers in the institution of higher education;

- acquaintance with the educational and methodical documentation of the department;

- attending classes of leading teachers of the department;

- development of plans-summaries of bulk classes;

- conducting training sessions with the obligatory presence of the head of the practice;

- participation in the organization or holding outside the training event.

The program of research practice and criteria for evaluating its results are developed by the head of practice, taking into account the research topics and interests of applicants and approved at the meeting of the department to which they are attached.

The results of the passing of pedagogical practice by future doctors of philosophy in the specialty "Law" are discussed during scientific and methodological seminars and meetings of the corresponding department. In 2016, the Academic Council of Zaporizhzhia National University adopted a regulation "On the procedure for submitting and reviewing dissertations in specialized academic councils of Zaporizhzhia National University", which provides for the personal responsibility of the chairman, scientific secretary, expert commissions, supervisors, and consultants of special councils for the quality of dissertations, prevention of academic plagiarism, a high level of demand during the examination of the study. This Regulation has become the direction of specialized scientific councils of the university.

Research practice is designed to expand the complex perception of the scientific problem that the applicant is dealing with. The bases of research practice are judicial and law enforcement agencies, enterprises, institutions, and organizations (there are 24 of them). This practice is managed by a scientific advisor and a representative of the practice base. 
Geduweb

Revista de Tecnología de Información y Comunicación en Educación • Volumen 15, Nㅜ 2. Mayo-agosto 2021

Upon completion of both pedagogical and research practice, the applicant prepares a corresponding report.

Based on the above, it is possible to conclude about the structural professional system of training doctors of philosophy in "Law" in Ukraine, in particular, on the example of Zaporizhzhia National University, which provides for the presence of two levels of education, theoretical and practical training at the stage of obtaining the degree of Doctor of Philosophy with certain programs, which are regulated by the internal documents of the higher education institution.

\section{Conclusions}

The process of training applicants for the degree of Doctor of Philosophy (Ph.D.) in the specialty "Law" at the Zaporizhzhia National University is a conceptually new format, which is aimed at the formation of theoretical and applied competencies consisting of two blocks: theoretical and practical. We have considered the main stages of training for applicants.

Relevant issues for further study are the following:

- search for a balance between educational and scientific elements in the system of training third-level higher education applicants;

- strengthening the inclusion of candidates for the degree of Doctor of Philosophy, in particular, for the specialty "Law" in the life of higher education;

- development of mechanisms of international educational and scientific programs at the third level of higher education;

- institutional possibilities of modernization of the system of obtaining the scientific degree of Doctor of Philosophy for the specialty "Law";

- autonomy of higher education institutions;

- introduction of meaningful scientific achievements into the strategy of each higher educational institution, and;

- strengthening the motivational component for scientific potential in the legal field.

\section{Reference}

Chesterfield, P. (2010). Letters to the Son. Moscow: World of Books, Literature. Available online. In: http://lingvo.asu.ru/english/texts/chester/chester78.html

Kornev, A. (2018). Theoretical foundations of practical jurisprudence. Bulletin of the University named after O.E. Kutafina, Vol. 4, pp. 20-29. Available online. In: https://vestnik.msal.ru/jour/article/view/458/458

Law 1556-VII/2014 of July 1 , about higher education. Bulletin of the Verkhovna Rada of Ukraine, 1 July 2014. Available online. In https://zakon.rada.gov.ua/laws/show/155618\#Text 
Law 2145-VIII/2017 of September 5, about education. Bulletin of the Verkhovna Rada of Ukraine, 38-39, 5 September, 2017, art. 380. Available online. In: https://zakon.rada.gov.ua/laws/show/2145-19

Ministry of Education and Science of Ukraine. (2021). Levels of the National Qualifications Framework. Available online. In: https://mon.gov.ua/ua/osvita/nacionalna-ramkakvalifikacij/rivni-nacionalnoyi-ramki-kvalifikacij

Ministry of Education and Science of Ukraine. Regulations No. 190/2018, on the implementation of the right of applicants for the third level of higher education of the degree of Doctor of Philosophy to freely choose academic disciplines at Zaporizhzhia National University. Available online. In: http://phd.znu.edu.ua/page/legal/3_znu_pro_v_l_nij_vib_r_PhD.pdf

Onishchuk, Y. (2020). Preparation of philosophy in the conditions of modern educational paradigm. Bulletin of the Academy of Labor, Social Relations and Tourism, Vol. 1-2, Pp. 7-10.

Panych, O. (2017). Preparation of doctors of philosophy: practices and problems / Preparation of doctors of philosophy (PhD) in the conditions of higher education reform. Proceedings of the All-Ukrainian scientific-practical conference, p. 12-17. Available online. In: http://phd.znu.edu.ua/page/img/Tezy_PHD_ZNU.pdf

Panych, O. (2018). Training of scientists: practices and problems. Osvita.ua. Available online. In: https://ru.osvita.ua/vnz/reform/58758/

Rashkevych, Y. (2020). About the new edition of the National Qualifications Framework. National Erasmus+ Office in Ukraine. Available online. In: https://erasmusplus.org.ua/novyny/3022-yu-rashkevych-pro-novu-redaktsiiunatsionalnoi-ramky-kvalifikatsii-01072020.html

Regulations 184/2019 of April 26, on the practice of third-level applicants for the degree of Doctor of Philosophy at Zaporizhzhia National University. Bulletin of the Verkhovna Rada of Ukraine, 26 April 2019. Available online. In: http://phd.znu.edu.ua/page/legal/4_znu_pol_pro_praktiku_PhD.pdf

Regulations 522/2000 of November 7, on the procedure for carrying out innovative educational activities. Bulletin of the Verkhovna Rada of Ukraine, 7 November 2000. Available online. In: http://zakon3.rada.gov.ua/laws/show/z0946-00

Resolution 261/2016 of March 23, on approval of the Procedure for training applicants for higher education for the degree of Doctor of Philosophy and Doctor of Science in higher educational institutions (scientific institutions). Bulletin of the Verkhovna Rada of Ukraine, 23 March 2016. Available online. In: https://zakon.rada.gov.ua/laws/show/261-2016-\%D0\%BF\#top

Schiller, F. (2018). Letters about the aesthetic education of man. Moscow: Ripol Classic Publishing House. ISBN 978-5-386-10464-1. Available online. In: https://dokumen.pub/9785386104641.html

Stepko, M., Bolyubash, Y., Shinkaruk, V., Grubinko V., \& Babyn, I. (2003). Bologna process in facts and documents. Ternopil: Ternopil Volodymyr Hnatiuk National Pedagogical University. Available online. In: http://aau.edu.ua/up/docs/bologna/bol_pr_in.pdf

Trebin, M. (2010). Sociology. Kharkiv: Pravo.

Zimnyaya, I, \& Shashenkova, O. (2001). Research work as a specific type of human activity. Izhevsk: Printing house of Udmurt University. Available online. In: https://eanbur.unatlib.ru/handle/123456789/3217 